\title{
To deprotect or not to deprotect: phosphonate ester versus phosphonic acid anchor ligands in copper(I)-based dye-sensitized solar cells
}

\author{
Frederik J. Malzner, Sven Y. Brauchli, Ewald Schönhofer, Edwin C. Constable* and \\ Catherine E. Housecroft* \\ Department of Chemistry, University of Basel, Spitalstrasse 51, 4056-Basel, Switzerland \\ Fax: +41 61267 1018; E-mail: catherine.housecroft@unibas.ch
}

\begin{abstract}
The performances of n-type DSCs containing the heteroleptic copper(I) dyes $[\mathrm{Cu}(\mathbf{1})(\mathrm{dmbpy})]^{+}$ and $[\mathrm{Cu}(\mathbf{2})(\mathrm{dmbpy})]^{+}\left(\mathbf{1}=\left(\left(6,6^{\prime}\right.\right.\right.$-dimethyl-[2,2'-bipyridine $]-4,4^{\prime}-$ diyl $)$ bis $(4,1-$ phenylene))bis(phosphonic acid); 2 = tetraethyl ((6,6'-dimethyl-[2,2'-bipyridine]-4,4'diyl)bis(4,1-phenylene))bis(phosphonate); dmbpy = 6,6'-dimethyl-2,2'-bipyridine) have been evaluated to determine whether or not deprotection of the phosphonate ester prior to assembly of the heteroleptic $\left[\mathrm{Cu}\left(\mathrm{L}_{\text {anchor }}\right)\left(\mathrm{L}_{\text {ancillary }}\right)\right]^{+}$dye is an essential step. Fully masked DSCs containing $[\mathrm{Cu}(\mathbf{1})(\mathrm{dmbpy})]^{+}$with $\mathrm{I}_{3}^{-} / \mathrm{I}^{-}$electrolyte show conversion efficiencies, $\eta$, of $\approx 2.1 \%$ compared to $\approx 0.3 \%$ for those containing $[\mathrm{Cu}(2)(\mathrm{dmbpy})]^{+}$in which 2 may be partially deprotected in situ. Compound $\mathbf{2}$ is a surprisingly effective ancillary ligand; DSCs containing $[\mathrm{Cu}(\mathbf{1})(\mathbf{2})]^{+}$exhibit $\eta \approx 2 \%$. EQE spectra for DSCs containing the dyes $[\mathrm{Cu}(\mathbf{1})(\mathrm{dmbpy})]^{+}$and $[\mathrm{Cu}(\mathbf{1})(2)]^{+}$are similar, showing broad bands with $\lambda_{\max }$ around $460-480 \mathrm{~nm}$ and $\mathrm{EQE}_{\max }=$ $40 \%$.
\end{abstract}

Keywords: Copper(I); bipyridine; phosphonic acid; phosphonate ester; solar cell; n-type 


\section{Introduction}

Fundamental to n-type dye-sensitized solar cells (DSCs) is a coloured dye (sensitizer) that is anchored to the surface of an n-type semiconductor, usually nanoparticular anatase $\left(\mathrm{TiO}_{2}\right)$. This dye allows the injection of electrons into the conduction band by visible light. Light-harvesting in Grätzel DSCs typically makes use of ruthenium(II) complexes [1,2], but their replacement by organic dyes [3] or metal complexes incorporating Earthabundant metals [4] is advantageous in the interests of establishing a cheaper and more sustainable technology. We and others are focusing both our experimental and theoretical attention on dyes in which the chromophore is a copper(I) complex $[4,5,6,7,8,9,10]$

Copper(I) diimine complexes are labile and the rapid ligand exchange processes $\left[{ }^{11}\right]$ predicate against the isolation of chemically pure heteroleptic complexes, making this a challenging goal [12]. The recognition of this lability allowed us to develop a method of assembling $\mathrm{TiO}_{2}$-bound heteroleptic $\left[\mathrm{Cu}\left(\mathrm{L}_{\text {anchor }}\right)\left(\mathrm{L}_{\text {ancillary }}\right)\right]^{+}$dyes directly on a surface [4]. The diimine ligand $\mathrm{L}_{\text {anchor }}$ is typically functionalized with carboxylic or phosphonic acid groups, with the latter exhibiting enhanced binding and temporal performance over the former [13]. We have found that, for 2,2'-bipyridine (bpy) anchoring ligands, the incorporation of a phenylene spacer between the bpy and anchor domains improves the performance of the $\left[\mathrm{Cu}\left(\mathrm{L}_{\text {anchor }}\right)\left(\mathrm{L}_{\text {ancillary }}\right)\right]^{+}$dye [8]. The bis(phosphonic acid) anchoring ligand $\mathbf{1}$ (Scheme 1) is prepared by deprotection of the corresponding ethyl ester 2 (Scheme 1) [8]. The most efficient method is reaction of $\mathbf{2}$ with aqueous $\mathrm{HCl}(6 \mathrm{M})$ at reflux for 2 days, followed by treatment of the residue with aqueous acetic acid at reflux. 2,2':6',2"-Terpyridine-4'-phosphonic acid ((4'(HO) $)_{2} \mathrm{OPtpy}$ ) and 2,2'-bipyridine-4,4'-diphosphonic acid have been used as anchoring ligands in n-type dyes incorporating $\left\{\mathrm{Ru}(\mathrm{tpy})_{2}\right\}^{2+},\left\{\mathrm{Ru}(\mathrm{tpy})\left(\mathrm{N}^{\wedge} \mathrm{N}\right) \mathrm{X}\right\}^{\mathrm{n}+}$ or $\left\{\mathrm{Ru}(\mathrm{bpy})_{2} \mathrm{X}_{2}\right\}^{\mathrm{n}+}\left(\mathrm{N}^{\wedge} \mathrm{N}=\right.$ 
diimine, $\mathrm{X}^{-}=\mathrm{NCS}^{-}, \mathrm{Cl}^{-}$or $\left.\mathrm{CN}^{-}\right)$chromophores $[14,15,16]$. These phosphonic acids are prepared by hydrolytic deprotection of the ruthenium-bound diethyl phosphonates, but reaction may not proceed to completion, terminating at the corresponding monoester, depending on reaction conditions $[14,15,17,18]$. Partial hydrolysis of diester ligands can also occur during complexation of the ester-functionalized ligands with ruthenium(II) $[16,19]$. In the light of these observations, together with the empirically observed better solubility of the phosphonate esters compared to the phosphonic acids, we decided to investigate the use of phosphonate ester 2 (Scheme 1) as an anchoring ligand. It is already established that phosphonate esters may be used to modify $\mathrm{TiO}_{2}$ surfaces under moderate conditions $[20,21]$ with surface immobilization occurring by hydrolysis of POR groups by surface $\mathrm{OH}$ functionalities [22].

All the ligands discussed in this work contain methyl substituents in the 6,6'-positions of the bpy domain. The presence of substituents ortho to the nitrogen donors is required to stabilize the $\{\mathrm{Cu} \text { (diimine) }\}_{2}^{+}$unit (tetrahedral or flattened tetrahedral) with respect to oxidation to $\left\{\mathrm{Cu}(\text { diimine })_{2}\right\}^{2+}$ (square planar) [23].
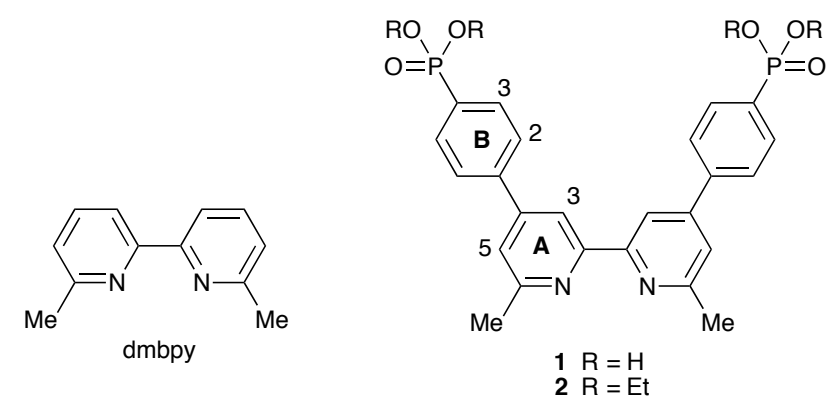

Scheme 1. Ligand structures and atom numbering for NMR spectroscopic assignments.

\section{Experimental}

\subsection{General}


${ }^{1} \mathrm{H}$ and ${ }^{13} \mathrm{C}$ NMR spectra were recorded on a Bruker Avance III-500 spectrometer with chemical shifts referenced to residual solvent peaks $(\partial(\mathrm{TMS})=0 \mathrm{ppm})$. Solution and solid state electronic absorption spectra were recorded on a Cary 5000 spectrophotometer; for the solid state spectra of the Electrospray ionization (ESI) mass spectra were recorded on a Bruker esquire $3000^{\text {plus }}$ mass spectrometer. TGA-MS measurements were carried out using a Mettler Toledo TGA/SDTA851e with Pfeiffer Vacuum Thermostar ${ }^{\text {TM }}$.

Ligands 1 [8] and 2 [8], [Cu(NCMe $\left.)_{4}\right]\left[\mathrm{PF}_{6}\right]$ [24] and [Cu(dmbpy $\left.)_{2}\right]\left[\mathrm{PF}_{6}\right]$ [25] were prepared by literature procedures. Abbreviation: dmbpy =6,6'-dimethyl-2,2'-bipyridine.

\section{$2.2 \quad\left[\mathrm{Cu}(2)_{2}\right]\left[\mathrm{PF} F_{6}\right]$}

Ligand 2 (200 mg, $0.329 \mathrm{mmol})$ was dissolved in $\mathrm{CH}_{2} \mathrm{Cl}_{2}(16 \mathrm{~mL})$ and $\mathrm{MeCN}(4 \mathrm{~mL})$ and $\left[\mathrm{Cu}(\mathrm{NCMe})_{4}\right]\left[\mathrm{PF}_{6}\right](61.2 \mathrm{mg}, 0.164 \mathrm{mmol})$ was added while the mixture was stirred. The reaction mixture was stirred at room temperature for $15 \mathrm{~h}$, after which time, the solvent was removed under reduced pressure. $\left[\mathrm{Cu}(2)_{2}\right]\left[\mathrm{PF}_{6}\right]$ was isolated as a dark red solid $(233 \mathrm{mg}$, $0.163 \mathrm{mmol}, 99.5 \%) .{ }^{1} \mathrm{H}$ NMR $\left(500 \mathrm{MHz}, \mathrm{CD}_{3} \mathrm{CN}\right) \partial / \mathrm{ppm} 8.72\left(\mathrm{~s}, 4 \mathrm{H}, \mathrm{H}^{\mathrm{A} 3}\right), 8.07\left(\mathrm{dd}, \mathrm{J}_{\mathrm{HH}}=\right.$ $\left.7.6 \mathrm{~Hz}, \mathrm{~J}_{\mathrm{PH}}=2.9 \mathrm{~Hz}, 8 \mathrm{H}, \mathrm{H}^{\mathrm{B} 2}\right), 7.97\left(\mathrm{dd}, \mathrm{J}_{\mathrm{PH}}=12.7 \mathrm{~Hz}, \mathrm{~J}_{\mathrm{HH}}=8.0 \mathrm{~Hz}, 8 \mathrm{H}, \mathrm{H}^{\mathrm{B} 3}\right), 7.88(\mathrm{~s}, 4 \mathrm{H}$, $\left.\mathrm{H}^{\mathrm{A} 5}\right), 4.15\left(\mathrm{~m}, 16 \mathrm{H}, \mathrm{H}^{\mathrm{Et}(\mathrm{CH} 2)}\right), 2.41\left(\mathrm{~s}, 12 \mathrm{H}, \mathrm{H}^{\mathrm{Me}}\right), 1.32\left(\mathrm{t}, \mathrm{J}=7.0 \mathrm{~Hz}, 24 \mathrm{H}, \mathrm{H}^{\mathrm{Et}(\mathrm{CH} 3)}\right) .{ }^{13} \mathrm{C} \mathrm{NMR}$ (126 MHz, $\left.\mathrm{CD}_{3} \mathrm{CN}\right) \partial$ / ppm: $159.0\left(\mathrm{C}^{\mathrm{A} 6}\right), 153.3\left(\mathrm{C}^{\mathrm{A} 2}\right), 150.0\left(\mathrm{C}^{\mathrm{A} 4}\right), 141.8\left(\mathrm{~d}, \mathrm{~J}_{\mathrm{PC}}=2.3 \mathrm{~Hz}\right.$, $\left.\mathrm{C}^{\mathrm{B} 1}\right), 133.3\left(\mathrm{~d}, \mathrm{~J}_{\mathrm{PC}}=10.3 \mathrm{~Hz}, \mathrm{C}^{\mathrm{B} 3}\right), 131.5\left(\mathrm{~d}, \mathrm{~J}_{\mathrm{PC}}=187.6 \mathrm{~Hz}, \mathrm{C}^{\mathrm{B} 4}\right), 128.7\left(\mathrm{~d}, \mathrm{~J}_{\mathrm{PC}}=14.8 \mathrm{~Hz}\right.$, $\left.\mathrm{C}^{\mathrm{B} 2}\right), 125.1\left(\mathrm{C}^{\mathrm{A} 5}\right), 119.2\left(\mathrm{C}^{\mathrm{A} 3}\right), 63.2\left(\mathrm{~d}, \mathrm{~J}_{\mathrm{PC}}=5.4 \mathrm{~Hz},\left(\mathrm{C}^{\mathrm{Et}(\mathrm{CH} 2)}\right), 25.4\left(\mathrm{C}^{\mathrm{Me}}\right), 16.6\left(\mathrm{~d}, \mathrm{~J}_{\mathrm{PC}}=6.2\right.\right.$ $\mathrm{Hz},\left(\mathrm{C}^{\mathrm{Et}(\mathrm{CH} 3)}\right)$. ESI MS m/z positive mode $1280.0\left[\mathrm{M}-\mathrm{PF}_{6}\right]^{+}$(calc. 1279.4), $609.5[\mathbf{2}+\mathrm{H}]^{+}$ (base peak, calc. 609.6); negative mode $144.9\left[\mathrm{PF}_{6}\right]^{-}$(calc. 145.0). UV-VIS $\left(\mathrm{CH}_{2} \mathrm{Cl}_{2}, 1.0 \times 10^{-}\right.$ $\left.{ }^{5} \mathrm{~mol} \mathrm{dm}^{-3}\right) \lambda / \mathrm{nm} 266\left(\varepsilon / \mathrm{dm}^{3} \mathrm{~mol}^{-1} \mathrm{~cm}^{-1} 73100\right), 325$ (35000), $357 \mathrm{sh}(8500), 490$ (11300). Found: C, 53.22, $\mathrm{H}, 5.89, \mathrm{~N}, 3.84 ; \mathrm{C}_{64} \mathrm{H}_{76} \mathrm{CuF}_{6} \mathrm{~N}_{4} \mathrm{O}_{12} \mathrm{P}_{5} \cdot \mathrm{H}_{2} \mathrm{O}$ requires $\mathrm{C}, 53.24, \mathrm{H}, 5.45, \mathrm{~N}$, 3.88 . 


\section{$2.3 \quad \mathrm{TiO}_{2}$ modified with 2}

The preparation method was based on that reported by Mutin [20]. $\mathrm{TiO}_{2}(190 \mathrm{mg})$ nanoparticles (Aeroxide ${ }^{\circledR} \mathrm{TiO}_{2} \mathrm{P} 25$, Evonik Industries AG) were added to a solution of 2 (1 $\mathrm{mM}$ ) in $\mathrm{CH}_{2} \mathrm{Cl}_{2}$ and left standing for $48 \mathrm{~h}$. The functionalized $\mathrm{TiO}_{2}$ was filtered, washed with $\mathrm{CH}_{2} \mathrm{Cl}_{2}$ and dried under high vacuum for $\sim 5 \mathrm{~h}$ before TGA-MS measurements.

\subsection{DSC fabrication}

DSCs were prepared adapting the method of Grätzel and coworkers [26]. For the photoanode, Solaronix Test Cell Titania Electrodes were used. The electrodes were rinsed with EtOH and sintered at $450{ }^{\circ} \mathrm{C}$ for $30 \mathrm{~min}$. The electrodes were cooled to $\approx 80{ }^{\circ} \mathrm{C}$ and immersed in a $1 \mathrm{mM}$ DMSO solution of 1 or a $1 \mathrm{mM} \mathrm{CH}_{2} \mathrm{Cl}_{2}$ solution of ester 2 for $24 \mathrm{~h}$. The colourless electrode was removed from the solution, washed with DMSO (for 1) or $\mathrm{CH}_{2} \mathrm{Cl}_{2}$ (for 2), followed by $\mathrm{EtOH}$ (for both) and was then dried with a heat-gun at $60^{\circ} \mathrm{C}$. The electrode was then immersed in a $0.1 \mathrm{mM} \mathrm{CH}_{2} \mathrm{Cl}_{2}$ solution of $\left[\mathrm{Cu}(\mathrm{dmbpy})_{2}\right]\left[\mathrm{PF}_{6}\right]$ or $\left[\mathrm{Cu}(2)_{2}\right]\left[\mathrm{PF}_{6}\right]$ for $\approx 68 \mathrm{~h}$, and during this time, the electrodes turned orange or pale orange, respectively. A reference cell was made by dipping the Solaronix electrode in a $0.3 \mathrm{mM}$ EtOH solution of standard dye N719 (Solaronix) for $\approx 68 \mathrm{~h}$; the electrode was then washed with EtOH and dried with a heat gun at $60{ }^{\circ} \mathrm{C}$. A Solaronix Test Cell Platinum Electrode were used for the counter electrode; residual organic impurities were removed by heating for $30 \mathrm{~min}$ at $450{ }^{\circ} \mathrm{C}$ on a heating plate.

The dye-covered $\mathrm{TiO}_{2}$ electrode and Pt counter-electrode were assembled using thermoplast hot-melt sealing foil (Solaronix Test Cell Gaskets) by heating while pressing them together. The electrolyte was a solution of $\operatorname{LiI}\left(0.1 \mathrm{~mol} \mathrm{dm}^{-3}\right), \mathrm{I}_{2}\left(0.05 \mathrm{~mol} \mathrm{dm}^{-3}\right), 1-$ methylbenzimidazole $\left(0.5 \mathrm{~mol} \mathrm{dm}^{-3}\right)$ and 1-butyl-3-methylimidazolinium iodide $\left(0.6 \mathrm{~mol} \mathrm{\textrm {dm } ^ { - }}\right.$ ${ }^{3}$ ) in methoxypropionitrile, and was introduced into the cell by vacuum backfilling. The hole 
on the counter electrode was finally sealed using the hot-melt sealing foil (Solaronix Test Cell Sealings) and a cover glass (Solaronix Test Cell Caps). Measurements were made by irradiating from behind using a light source SolarSim 150 (100 $\left.\mathrm{W} \mathrm{m}^{-2}=1 \mathrm{sun}\right)$ or LOT Quantum Design LS0811 (100 $\mathrm{W} \mathrm{m}^{-2}=1$ sun). The power of the simulated light was calibrated by using a reference Si cell.

\subsection{External quantum efficiency (EQE) measurements}

The external quantum efficiency measurements were performed on a Spe-Quest quantum efficiency setup from Rera Systems (Netherlands) equipped with a $100 \mathrm{~W}$ halogen lamp (QTH) and a lambda 300 grating monochromator from Lot Oriel. The monochromatic light was modulated to $3 \mathrm{~Hz}$ using a chopper wheel from ThorLabs. The cell response was amplified with a large dynamic range IV converter from CVI Melles Griot and then measured with a SR830 DSP Lock-In amplifier from Stanford Research.

\subsection{DFT calculations}

Ground state DFT calculations were performed using Spartan 14 (v. 1.1.3) at the B3LYP level with a $6-31 G^{*}$ basis set in vacuum. Initial energy optimization was carried out at a semiempirical (PM3) level.

\section{$3 \quad$ Results and discussion}

\subsection{Synthesis and characterization of $\left[\mathrm{Cu}(2)_{2}\right][\mathrm{PF} 6]$}

Ligand $\mathbf{2}$ was prepared as previously described [8] and two equivalents of $\mathbf{2}$ were reacted with $\left[\mathrm{Cu}(\mathrm{NCMe})_{4}\right]\left[\mathrm{PF}_{6}\right]$ in $\mathrm{CH}_{2} \mathrm{Cl}_{2}$. This gave dark red $\left[\mathrm{Cu}(2)_{2}\right]\left[\mathrm{PF}_{6}\right]$ in quantitative yield. The electrospray mass spectrum was recorded in both positive and negative modes. In the latter, a peak at $m / z 144.9$ was observed for the $\left[\mathrm{PF}_{6}\right]^{-}$ion. In positive mode, the base peak was 
observed at $\mathrm{m} / \mathrm{z} 609.5$ and assigned to $[2+\mathrm{H}]^{+}$; a lower intensity peak envelope at $\mathrm{m} / \mathrm{z} 1280.0$ was consistent with $\left[\mathrm{M}-\mathrm{PF}_{6}\right]^{+}$and the isotope pattern matched that simulated for this ion. The ${ }^{1} \mathrm{H}$ and ${ }^{13} \mathrm{C}$ NMR spectra of a $\mathrm{CD}_{3} \mathrm{CN}$ solution of $\left[\mathrm{Cu}(2)_{2}\right]\left[\mathrm{PF}_{6}\right]$ each exhibited a set of signals consistent with the symmetrical ligand 2 . The ${ }^{13} \mathrm{C}$ NMR spectrum was similar to that of the free ligand 2 in the same solvent [8] with values of $\mathrm{J}_{\mathrm{PC}}$ of $187.7,10.3,14.8$ and $2.3 \mathrm{~Hz}$ for atoms $\mathrm{C}^{\mathrm{B} 4}, \mathrm{C}^{\mathrm{B} 3}, \mathrm{C}^{\mathrm{B} 2}$ and $\mathrm{C}^{\mathrm{B} 1}$, respectively (see Scheme 1 for numbering). In the ${ }^{1} \mathrm{H} \mathrm{NMR}$ spectrum, signals for $\mathrm{H}^{\mathrm{B} 2}$ and $\mathrm{H}^{\mathrm{B} 3}$ are resolved in contrast to their overlap in the spectrum of the free ligand. Signals assigned to bpy protons $\mathrm{H}^{\mathrm{A} 5}(\partial 7.59 \mathrm{ppm})$ and $\mathrm{H}^{\mathrm{A} 3}(\partial 8.57 \mathrm{ppm})$ in ligand $\mathbf{2}$ are shifted upon coordination to copper(I) to $\partial 7.88$ and $8.72 \mathrm{ppm}$, respectively.

Figure 1 shows the absorption spectrum of $\left[\mathrm{Cu}(2)_{2}\right]\left[\mathrm{PF}_{6}\right]$ recorded in $\mathrm{CH}_{2} \mathrm{Cl}_{2}$. The spectrum extends well into the visible region with the band at $490 \mathrm{~nm}$ arising from MLCT transitions, and the intense, high energy bands arising from spin-allowed, ligand-based $\pi^{*} \leftarrow \pi$ transitions. The extinction coefficient for the MLCT band is of the same order of magnitude as for related complexes containing $\left\{\mathrm{Cu}^{\mathrm{I}}\left(4,4^{\prime} \text {-diphenylbpy }\right)_{2}\right\}$ cores $\left[^{8}\right]$.

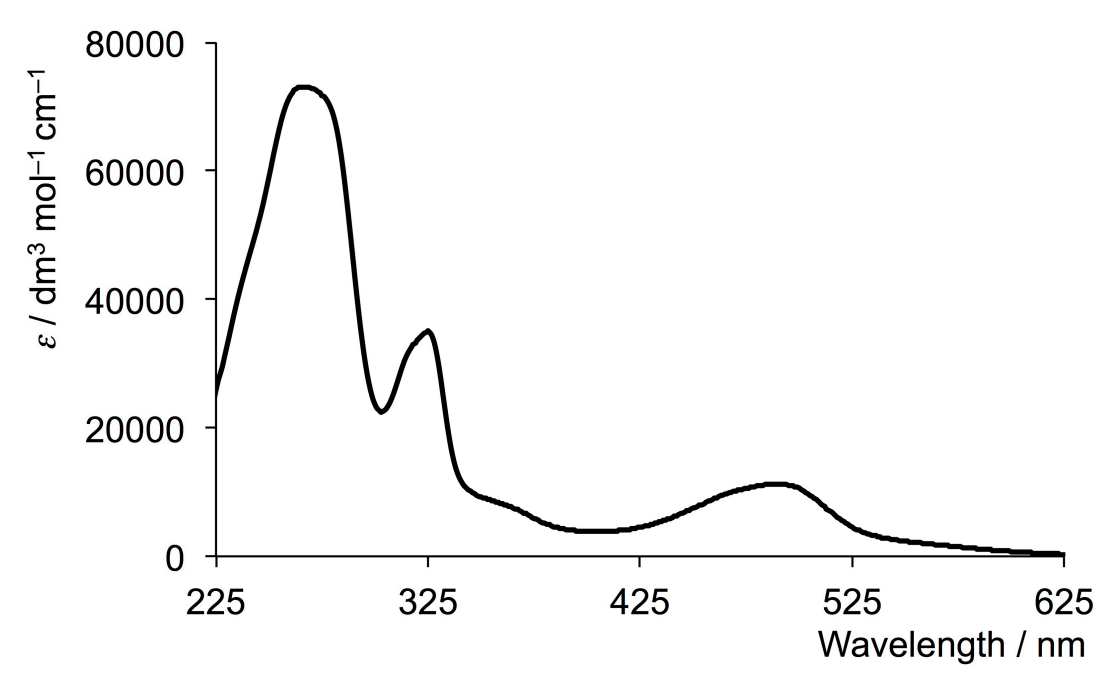

Fig. 1. Solution absorption spectrum of $\left[\mathrm{Cu}(2)_{2}\right]\left[\mathrm{PF}_{6}\right]\left(\mathrm{CH}_{2} \mathrm{Cl}_{2}, 1 \times 10^{-5} \mathrm{~mol} \mathrm{dm}^{-3}\right)$. 
Attempts to prepare the homoleptic complex $\left[\mathrm{Cu}(\mathbf{1})_{2}\right]\left[\mathrm{PF}_{6}\right]$ failed. Initially, colourless $\left[\mathrm{Cu}(\mathrm{NCMe})_{4}\right]\left[\mathrm{PF}_{6}\right]$ and ligand 1 were reacted under the same room temperature conditions used to prepare $\left[\mathrm{Cu}(2)_{2}\right]\left[\mathrm{PF}_{6}\right]$. Only starting materials were recovered. The solvent for the reaction was changed from $\mathrm{MeCN} / \mathrm{CH}_{2} \mathrm{Cl}_{2}$ to DMF and finally to DMSO, and the temperature of the reaction was correspondingly increased from room temperature to $80^{\circ} \mathrm{C}$ and finally to $100{ }^{\circ} \mathrm{C}$, and the reaction time was extended to 10 days. No change in colour was observed; a change from colourless to red would be characteristic of diimine coordination to copper(I). One possible reason for the failure of 1 to react with $\left[\mathrm{Cu}(\mathrm{NCMe})_{4}\right]^{+}$may be due to changes in the protonation state of the phosphonic acids groups in $\mathbf{1}$.

\subsection{TGA-MS and solid-state absorption spectroscopic study of the binding of 2 to $\mathrm{TiO}_{2}$}

The ability of ester 2 to anchor to $\mathrm{TiO}_{2}$ was investigated using TGA-MS. First, the TGA-MS trace of solid $2(5.5 \mathrm{mg})$ was recorded with the mass spectrometer set at $m / z=18,30$ and 46 to detect $\mathrm{H}_{2} \mathrm{O}, \mathrm{C}_{2} \mathrm{H}_{6}$ and EtOH, respectively. The first weight loss occurred at $330{ }^{\circ} \mathrm{C}$ and corresponded to $27 \%$ of the sample with $\mathrm{H}_{2} \mathrm{O}, \mathrm{C}_{2} \mathrm{H}_{6}$ and EtOH all being detected. A second mass loss $\left(450-480{ }^{\circ} \mathrm{C}\right)$ also corresponded to loss of $\mathrm{H}_{2} \mathrm{O}$. A sample of $\mathrm{TiO}_{2}$ modified with 2 was prepared in a similar manner to the phosphonate-modified $\mathrm{TiO}_{2}$ reported by Mutin and coworkers [20]. The TGA-MS trace of the $\mathrm{TiO}_{2} / \mathbf{2}$ sample with the mass spectrometer set to detect $\mathrm{H}_{2} \mathrm{O}, \mathrm{C}_{2} \mathrm{H}_{6}$ and EtOH showed only loss of $\mathrm{H}_{2} \mathrm{O}$ at $\approx 80{ }^{\circ} \mathrm{C}$.

Since the TGA failed to confirm successful modification of $\mathrm{TiO}_{2}$ with $\mathbf{2}$ at room temperature, we decided to use solid-state absorption spectroscopy to provide evidence for adsorption of $[\mathrm{Cu}(2)(\mathrm{dmbpy})]^{+}$on $\mathrm{TiO}_{2}$. $\mathrm{FTO} / \mathrm{TiO}_{2}$ electrodes (without a scattering layer) were prepared by successive dipping of the electrode into a $\mathrm{CH}_{2} \mathrm{Cl}_{2}$ solution of $2(1 \mathrm{mM}$, room temperature overnight) followed by a $\mathrm{CH}_{2} \mathrm{Cl}_{2}$ solution of $\left[\mathrm{Cu}(\mathrm{dmbpy})_{2}\right]\left[\mathrm{PF}_{6}\right](0.1 \mathrm{mM}, \approx 68 \mathrm{~h})$. The electrode was washed with $\mathrm{CH}_{2} \mathrm{Cl}_{2}$ between the two dipping cycles. A second electrode 
was prepared in an analogous manner but was additionally heated for 30 minutes at $350{ }^{\circ} \mathrm{C}$ after treatment of $\mathrm{TiO}_{2}$ with 2 ; we aimed to encourage hydrolytic deprotection of the ester leading to enhanced coverage of the surface with half-ester or phosphonic acid anchoring ligand. Photographs of the two dye-functionalized electrodes are shown in Figure 2a. Both electrodes are coloured, the non-heat treated electrode appearing pale orange and the heat treated electrode yellow. Figure $2 \mathrm{~b}$ shows their solid-state absorption spectra. Each spectrum was corrected for the background spectrum of a blank electrode. The electrode assembled under ambient conditions shows a band with $\lambda_{\max }=470 \mathrm{~nm}$ which compares with $490 \mathrm{~nm}$ for the MLCT band in the $\mathrm{CH}_{2} \mathrm{Cl}_{2}$ solution absorption spectrum of $\left[\mathrm{Cu}(2)_{2}\right]\left[\mathrm{PF}_{6}\right]$. For the heattreated electrode, only a weak shoulder at $\approx 470 \mathrm{~nm}$ is observed. The solid-state absorption spectroscopic data indicate that $\mathbf{2}$ can function as an anchoring ligand, probably after in situ deprotection (partially to the monoester or fully to the acid).

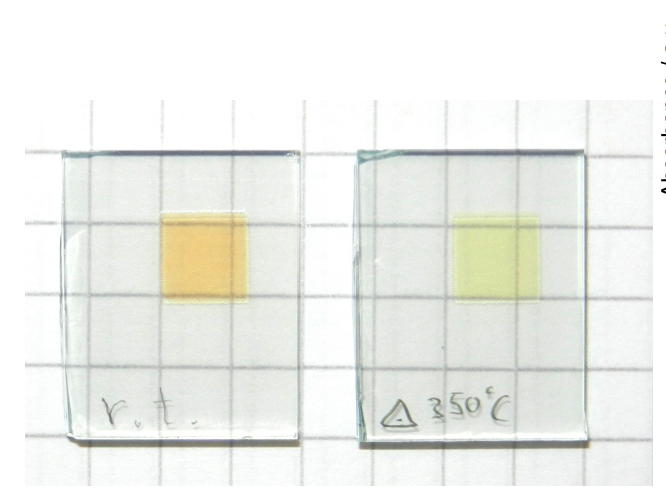

(a)

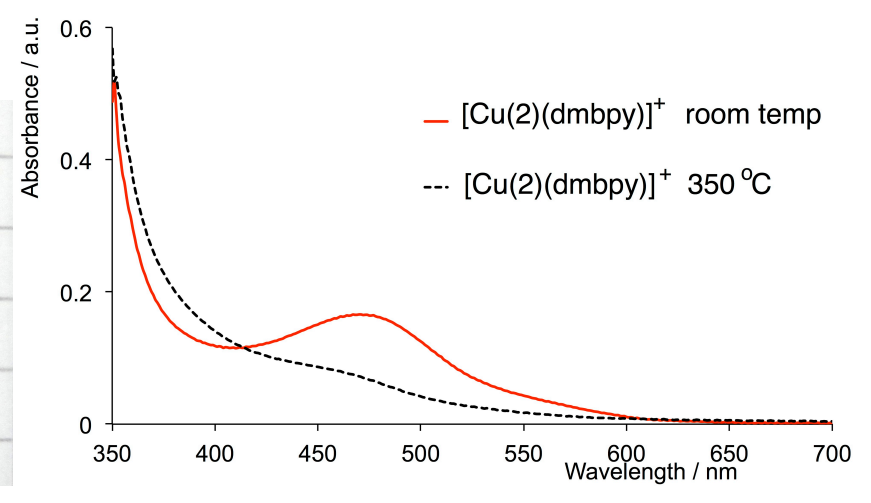

(b)

Fig. 2 (a) $\mathrm{FTO} / \mathrm{TiO}_{2}$ electrodes treated (left) with $\mathrm{CH}_{2} \mathrm{Cl}_{2}$ solutions of 2 and $\left[\mathrm{Cu}(\mathrm{dmbpy})_{2}\right]\left[\mathrm{PF}_{6}\right]$ at room temperature, and (right) with $\mathrm{CH}_{2} \mathrm{Cl}_{2}$ solution of 2 followed by drying and heating at $350{ }^{\circ} \mathrm{C}$ for $30 \mathrm{~min}$., and then a $\mathrm{CH}_{2} \mathrm{Cl}_{2}$ solution of $\left[\mathrm{Cu}(\mathrm{dmbpy})_{2}\right]\left[\mathrm{PF}_{6}\right]$. (b) The solid-state absorption spectra of the two electrodes.

\subsection{Assembly and performance of DSCs}

In order to compare the performance of heteroleptic dyes containing $\mathbf{1}$ or $\mathbf{2}$ as the anchoring domain, we chose dmbpy (Scheme 1) as an ancillary ligand. Nanoparticulate $\mathrm{TiO}_{2}$-surface 
anchored heteroleptic dyes $[\mathrm{Cu}(\mathbf{1})(\mathrm{dmbpy})]^{+}$and $[\mathrm{Cu}(\mathbf{2})(\mathrm{dmbpy})]^{+}$were assembled by sequential dipping of the photoanode into solutions of (i) $\mathbf{1}$ or $\mathbf{2}$, followed by (ii) $\left[\mathrm{Cu}(\mathrm{dmbpy})_{2}\right]\left[\mathrm{PF}_{6}\right]$. After the last dipping cycle, the electrodes with $[\mathrm{Cu}(\mathbf{1})(\mathrm{dmbpy})]^{+}$were orange and the colour persisted when the electrode was washed; electrodes with $[\mathrm{Cu}(2)(\mathrm{dmbpy})]^{+}$were very pale orange. The retention of this colour after washing suggested that at least a small amount of the dye was anchored to the electrode, consistent with the spectroscopic data in Figure 2b.

The DSCs were then fabricated as detailed in the experimental section using an $\mathrm{I}_{3}^{-} / \mathrm{I}^{-}$ electroyte, and were fully masked [27] for all efficiency measurements. A reference DSC with standard dye N719 was also prepared. Solar conversion efficiencies $(\eta)$ were measured on the day of sealing the DSC and 3 days after sealing. In previous studies of copper(I)-based dyes, we have often observed a ripening effect (i.e. enhancement of performance with time) $[5,25,28]$ and we routinely assess how the performance of a dye changes over days or weeks after fabricating the DSC. Values of the open circuit voltage $\left(V_{\mathrm{OC}}\right)$, short circuit current density $\left(J_{\mathrm{SC}}\right)$, fill factor $(f f)$ and $\eta$ are given in Table 1 ; duplicate DSCs were made for each copper(I) dye. Figure 3 shows the $J-V$ curves for the DSCs on the day of sealing the cells; similar curves were obtained after three days (see Table 1). The right-hand column of Table 1 gives a relative efficiency, setting the value recorded for N719 to $100 \%$. We find this a useful means of comparing data, especially when they are recorded on different solar simulators, either within our or in different laboratories. To underline this point, we measured the DSC characteristics of the same cells and on the same day on two sun simulators (both under irradiation of 1 sun). Both instruments were calibrated against a silicon standard. A comparison of the parameters in Table 2 with those in the top part of Table 1 reveals similar values of $V_{\mathrm{OC}}$ for a given DSC, but consistently lower values of $J_{\mathrm{SC}}$ in Table 2, resulting in 
lower absolute values of $\eta$ for the second instrument. However, relative $\eta$ values in the righthand columns in the two tables are comparable.

Table 1. Performances of masked DSCs using dyes $[\mathrm{Cu}(\mathbf{1})(\mathrm{dmbpy})]^{+}$and $[\mathrm{Cu}(\mathbf{2})(\mathrm{dmbpy})]^{+}$. Measurements made using a SolarSim $150\left(100 \mathrm{~W} \mathrm{~m}^{-2}=1 \mathrm{sun}\right)$ instrument.

\begin{tabular}{|c|c|c|c|c|c|}
\hline Dye & $J_{\mathrm{SC}} / \mathrm{mA} \mathrm{cm}^{-2}$ & $V_{\mathrm{OC}} / \mathrm{mV}$ & $f f / \%$ & $\eta / \%$ & Relative $\eta / \%^{\mathrm{a}}$ \\
\hline \multicolumn{6}{|c|}{ On the day of sealing the cell } \\
\hline$[\mathrm{Cu}(\mathbf{1})(\mathrm{dmbpy})]^{+}$ & 5.55 & 522 & 72.0 & 2.08 & 27.9 \\
\hline$[\mathrm{Cu}(\mathbf{1})(\mathrm{dmbpy})]^{+}$ & 5.29 & 519 & 72.5 & 1.99 & 26.7 \\
\hline$\overline{[\mathrm{Cu}(\mathbf{2})(\mathrm{dmbpy})]^{+}}$ & 1.07 & 465 & 63.9 & 0.32 & 4.3 \\
\hline$[\mathrm{Cu}(\mathbf{2})(\mathrm{dmbpy})]^{+}$ & 1.26 & 465 & 64.6 & 0.38 & 5.1 \\
\hline N719 & 15.63 & 655 & 72.7 & 7.45 & 100 \\
\hline \multicolumn{6}{|c|}{3 Days after sealing the cell } \\
\hline$[\mathrm{Cu}(\mathbf{1})(\mathrm{dmbpy})]^{+}$ & 5.39 & 543 & 72.5 & 2.12 & 26.1 \\
\hline$[\mathrm{Cu}(\mathbf{1})(\mathrm{dmbpy})]^{+}$ & 5.37 & 559 & 71.1 & 2.14 & 26.4 \\
\hline$[\mathrm{Cu}(\mathbf{2})(\mathrm{dmbpy})]^{+}$ & 0.82 & 461 & 63.4 & 0.24 & 3.0 \\
\hline$[\mathrm{Cu}(\mathbf{2})(\mathrm{dmbpy})]^{+}$ & 0.97 & 458 & 64.5 & 0.29 & 3.6 \\
\hline N719 & 16.75 & 666 & 72.7 & 8.12 & 100 \\
\hline
\end{tabular}

Table 2. Performances of masked DSCs (the same cells as in Table 1) using dyes $[\mathrm{Cu}(\mathbf{1})(\mathrm{dmbpy})]^{+}$and $[\mathrm{Cu}(\mathbf{2})(\mathrm{dmbpy})]^{+}$. Measurements made using a LOT Quantum Design $\left(100 \mathrm{~W} \mathrm{~m}^{-2}=1\right.$ sun) sun simulator.

\begin{tabular}{|l|l|l|l|l|l|l|}
\hline Dye & $J_{\mathrm{SC}} / \mathrm{mA} \mathrm{cm}^{-2}$ & $V_{\mathrm{OC}} / \mathrm{mV}$ & $f f / \%$ & $\eta / \%$ & Relative $\eta / \%{ }^{\mathrm{a}}$ \\
\hline \multicolumn{7}{|c|}{ On the day of sealing the cell } \\
\hline$[\mathrm{Cu}(\mathbf{1})(\text { dmbpy })]^{+}$ & 3.79 & 522 & 73.8 & 1.46 & 24.7 \\
\hline$\left[\mathrm{Cu}(\mathbf{1})(\text { dmbpy) }]^{+}\right.$ & 3.46 & 527 & 74.3 & 1.35 & 22.8 \\
\hline$[\mathrm{Cu}(\mathbf{2})(\text { dmbpy })]^{+}$ & 0.77 & 470 & 72.0 & 0.26 & 4.4 \\
\hline$\left[\mathrm{Cu}(\mathbf{2})(\text { dmbpy) }]^{+}\right.$ & 0.87 & 467 & 71.5 & 0.29 & 4.9 \\
\hline $\mathrm{N} 719$ & 12.51 & 672 & 70.2 & 5.91 & 100 \\
\hline
\end{tabular}


An important observation in both Tables 1 and 2 is that the cell parameters are reproducible within experimental error within pairs of cells with the same ligand combinations. The data indicate that DSCs containing $[\mathrm{Cu}(\mathbf{1})(\mathrm{dmbpy})]^{+}$with the phosphonic acid anchor perform significantly better than DSCs with a dye anchored using the phosphonate ester. Very low values of $J_{\mathrm{SC}}$ are most detrimental to the performance of $[\mathrm{Cu}(2)(\mathrm{dmbpy})]^{+}$. The parameters in Table 1 show that no ripening effect is observed over a three day period for DSCs with $[\mathrm{Cu}(\mathbf{1})(\mathrm{dmbpy})]^{+}$, indicating that the dye molecules undergo little or no reorganization on the surface affecting the efficiency over this period. Presumably this is associated with the fact that the ancillary ligands are relatively sterically unhindered and an optimum surface coverage is achieved during the electrode-dipping process. The external quantum efficiency (EQE) spectra shown in Figure 4 exhibit band maxima at $470 \mathrm{~nm}$ for $[\mathrm{Cu}(\mathbf{1})(\mathrm{dmbpy})]^{+}$and $490 \mathrm{~nm}$ for $[\mathrm{Cu}(2)(\mathrm{dmbpy})]^{+}$with corresponding EQE maxima of 42 and $38 \%$ for the two DSCs containing $[\mathrm{Cu}(\mathbf{1})(\mathrm{dmbpy})]^{+}$and 8 and $10 \%$ for $[\mathrm{Cu}(\mathbf{2})(\mathrm{dmbpy})]^{+}$. This is either an indication that the phosphonate ester is an inferior anchoring ligand, or can be explained through in situ formation of some monoester and/or phosphonic acid anchoring domain leading to lower dye loading. 


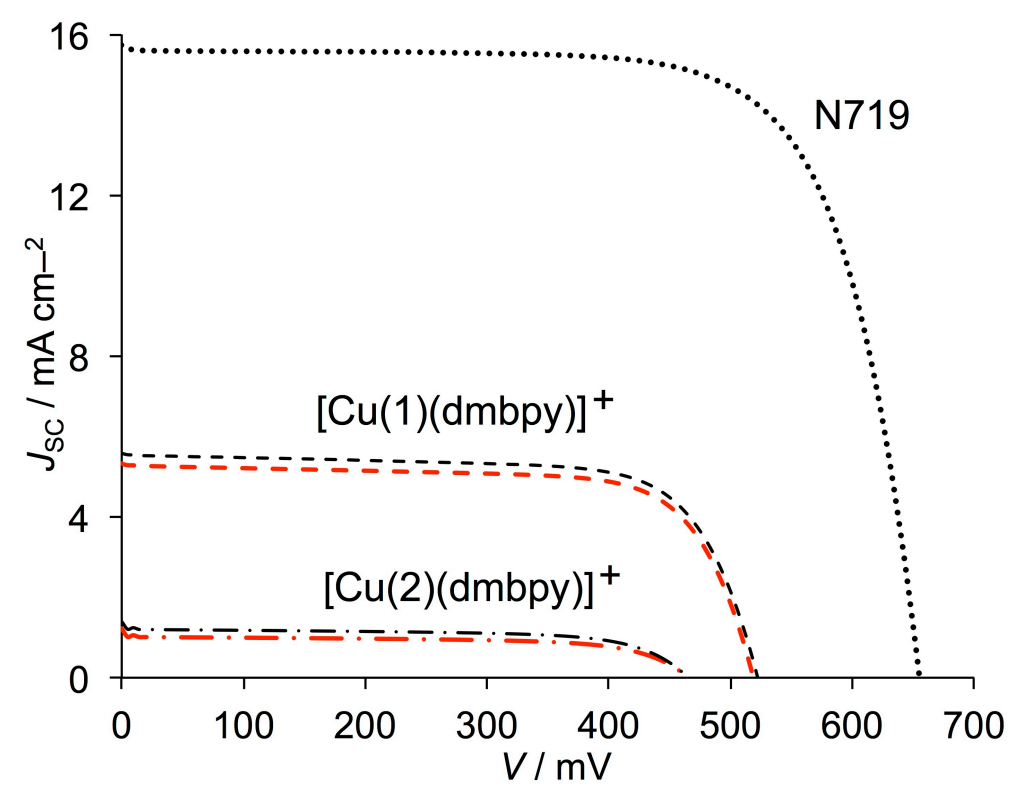

Fig. 3. Current density-voltage curves for DSCs functionalized with dyes $[\mathrm{Cu}(\mathbf{1})(\mathrm{dmbpy})]^{+}$ and $[\mathrm{Cu}(2)(\mathrm{dmbpy})]^{+}$on the day of sealing compared to N719 measured under the same conditions. Black lines $=$ cell 1; red $=$ cell 2 (see Fig. 3 ).

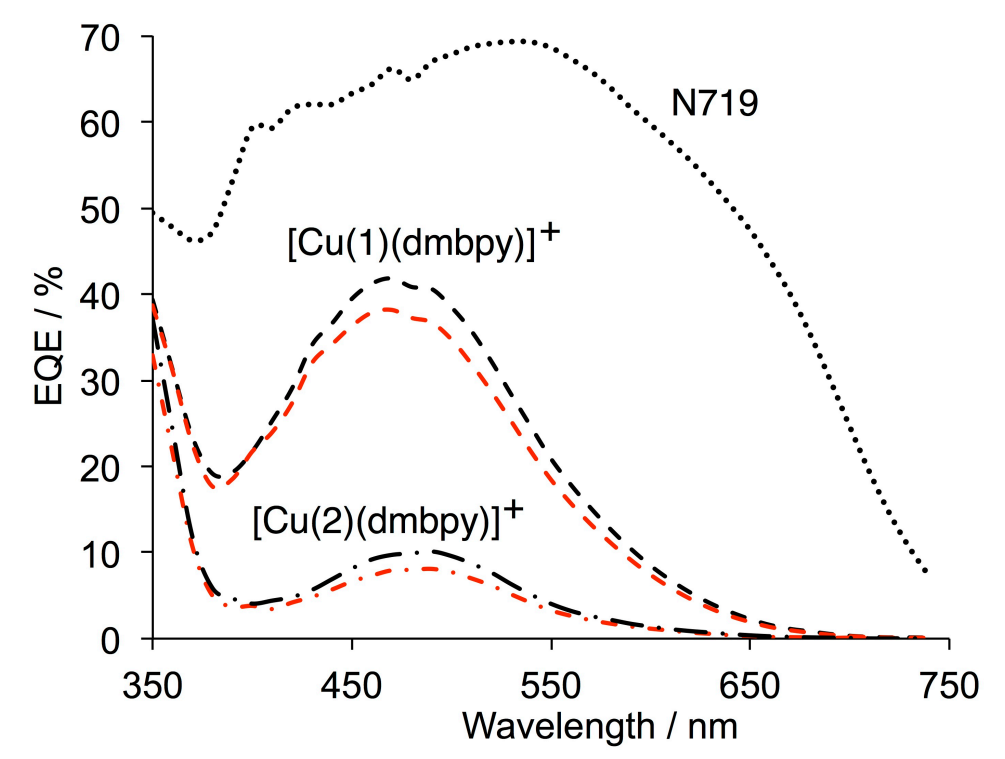

Fig. 4. EQE spectra for DSCs functionalized with dyes $[\mathrm{Cu}(\mathbf{1})(\mathrm{dmbpy})]^{+}$and $[\mathrm{Cu}(\mathbf{2})(\mathrm{dmbpy})]^{+}$ on the day of sealing compared to N719. Black and red lines correspond to the same DSCs as in Fig. 3.

We have also investigated the effectiveness of ligand $\mathbf{2}$ as an ancillary ligand. The surface-bound complex $[\mathrm{Cu}(\mathbf{1})(2)]^{+}$was prepared by sequential dipping of the electrode in a 
DMSO solution of 1 followed by a $\mathrm{CH}_{2} \mathrm{Cl}_{2}$ solution of $\left[\mathrm{Cu}(2)_{2}\right]\left[\mathrm{PF}_{6}\right]$. Two DSCs were made and the performance data are given in Table $3 ; J-V$ curves are shown in Figure 5. Considering that the ancillary ligand has not been specially designed for its role in photon harvesting, the DSCs perform remarkably well, showing good open-circuit voltages and values for power conversion efficiences of close to $2 \%$. Values of $J_{\mathrm{SC}}$ are significantly lower than for N719 (Table 3), but are comparable with those of some of the better performing $\left\{\mathrm{Cu}^{\mathrm{I}}(\text { diimine })_{2}\right\}$ dyes combined with $\mathrm{I}_{3}^{-} / \mathrm{I}^{-}$electrolyte $[8,25,29]$. EQE curves for the DSCs (Figure 6) show band maxima at $470 \mathrm{~nm}$ with $\mathrm{EQE}_{\max }$ values of 40.0 and $40.7 \%$ for the two cells, and curves with similar profiles to those for $[\mathrm{Cu}(\mathbf{1})(\mathrm{dmbpy})]^{+}$with the simple ancillary ligand. This indicates that electron injection within the 350-700 $\mathrm{nm}$ range for $[\mathrm{Cu}(\mathbf{1})(\mathrm{dmbpy})]^{+}$and $[\mathrm{Cu}(\mathbf{1})(\mathbf{2})]^{+}$is comparable.

Table 3. Performances of masked DSCs using dyes $[\mathrm{Cu}(\mathbf{1})(\mathbf{2})]^{+}$compared to N719. Measurements made using a SolarSim $150\left(100 \mathrm{~W} \mathrm{~m}^{-2}=1 \mathrm{sun}\right)$ instrument.

\begin{tabular}{|l|l|l|l|l|l|l|}
\hline Dye & $J_{\mathrm{SC}} / \mathrm{mA} \mathrm{cm}^{-2}$ & $V_{\mathrm{OC}} / \mathrm{mV}$ & $f f / \%$ & $\eta / \%$ & Relative $\eta / \%^{\mathrm{a}}$ \\
\hline \multicolumn{7}{|c|}{ On the day of sealing the cell } \\
\hline$[\mathrm{Cu}(\mathbf{1})(\mathbf{2})]^{+}$ & 5.23 & 516 & 71.6 & 1.93 & 29.2 \\
\hline$[\mathrm{Cu}(\mathbf{1})(\mathbf{2})]^{+}$ & 5.61 & 520 & 71.1 & 2.07 & 31.3 \\
\hline $\mathrm{N} 719$ & 16.29 & 587 & 69.2 & 6.61 & 100 \\
\hline \multicolumn{7}{|l|}{3 Days after sealing the cell } \\
\hline$[\mathrm{Cu}(\mathbf{1})(\mathbf{2})]^{+}$ & 5.38 & 550 & 70.7 & 2.09 & 27.4 \\
\hline$[\mathrm{Cu}(\mathbf{1})(\mathbf{2})]^{+}$ & 5.41 & 523 & 71.1 & 2.01 & 26.3 \\
\hline $\mathrm{N} 719$ & 17.03 & 640 & 70.1 & 7.64 & 100 \\
\hline
\end{tabular}




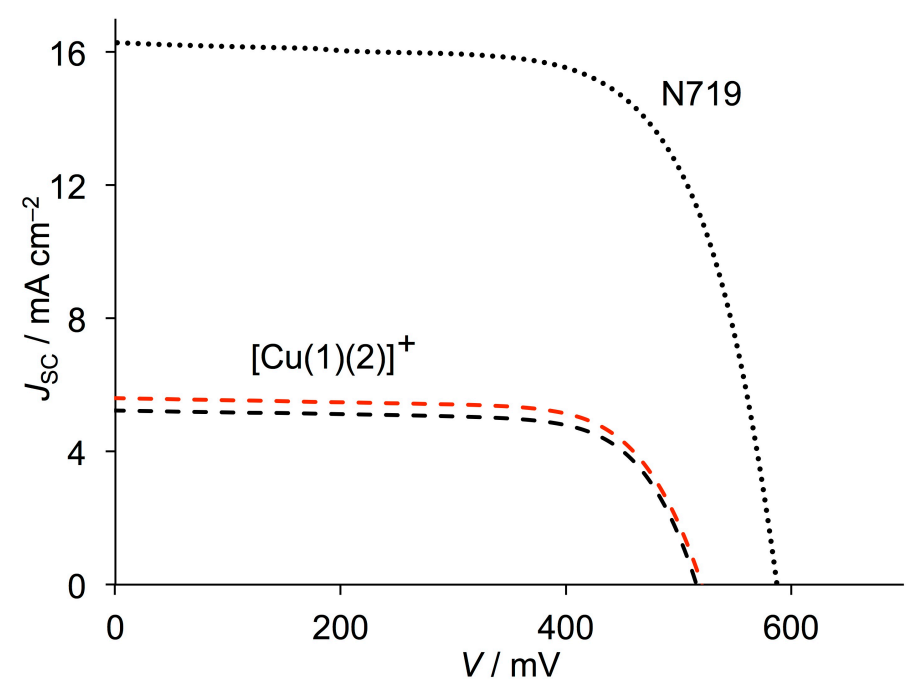

Fig. 5. Current density-voltage curves for DSCs functionalized with the dye $[\mathrm{Cu}(\mathbf{1})(\mathbf{2})]^{+}$on the day of sealing compared to N719 measured under the same conditions. Black lines $=$ cell 1 ; red $=$ cell 2 (see Fig. 6).

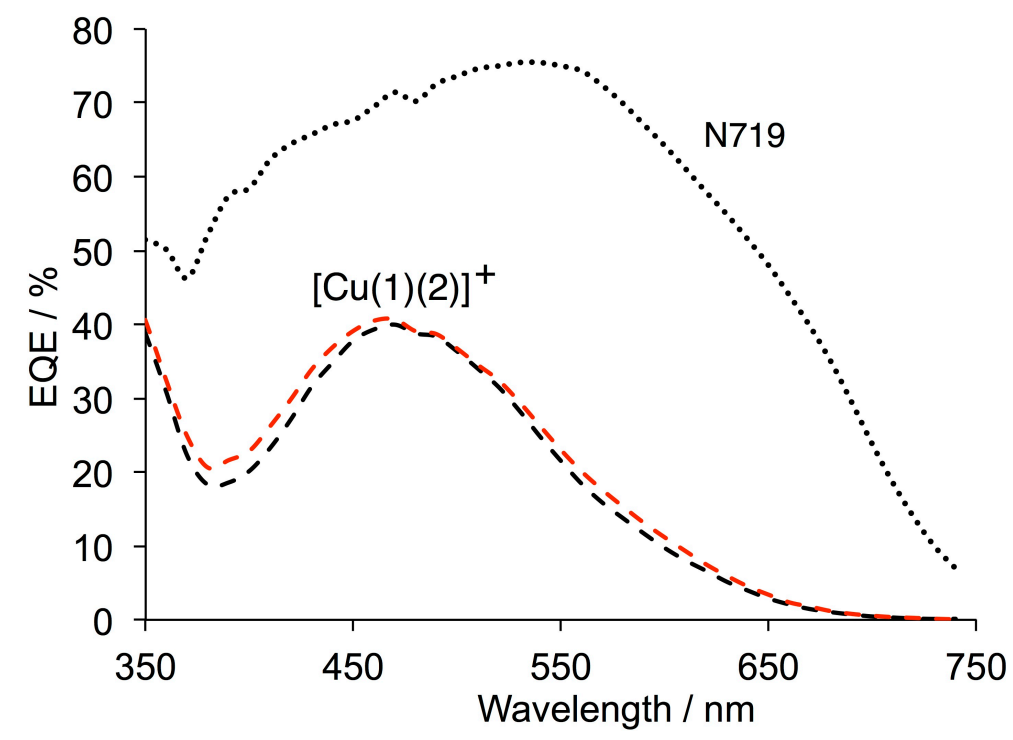

Fig. 6. EQE spectra for DSCs functionalized with the dye $[\mathrm{Cu}(\mathbf{1})(\mathbf{2})]^{+}$on the day of sealing the cells compared to N719. Black and red lines correspond to the same DSCs as in Fig. 5.

DFT calculations on the ground state, energy minimized structures of $[\mathrm{Cu}(\mathbf{1})(\mathrm{dmbpy})]^{+}$ and $[\mathrm{Cu}(\mathbf{1})(2)]^{+}$showed that the energies and characteristics of the HOMOs and LUMOs of the two complexes are similar, consistent with their similar performances as sensitizers 
(assuming similar surface coverages). Figure 7 illustrates that the LUMO of both $[\mathrm{Cu}(\mathbf{1})(\mathrm{dmbpy})]^{+}$and $[\mathrm{Cu}(\mathbf{1})(\mathbf{2})]^{+}$is localized on the anchoring ligand $\mathbf{1}$ and the HOMO on the ancillary ligand, characteristics that are appropriate for an n-type dye.

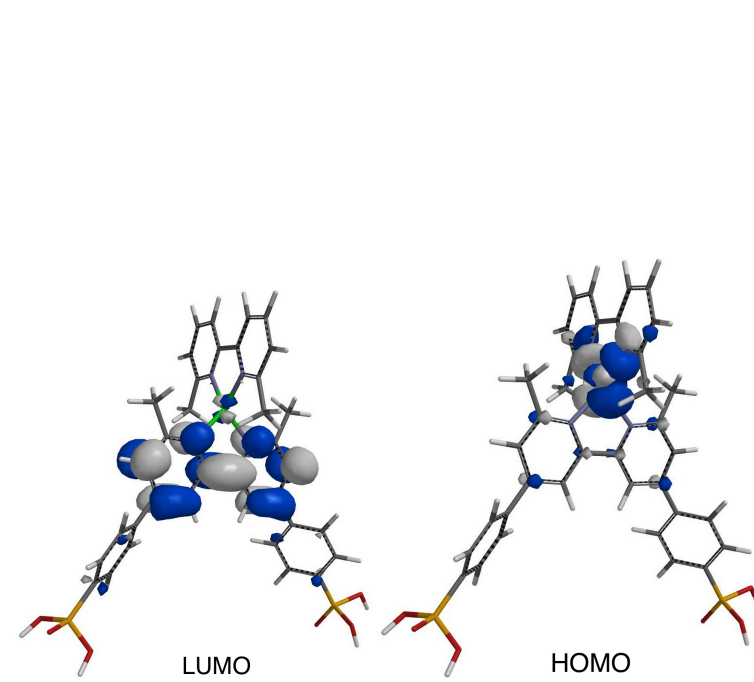

(a)

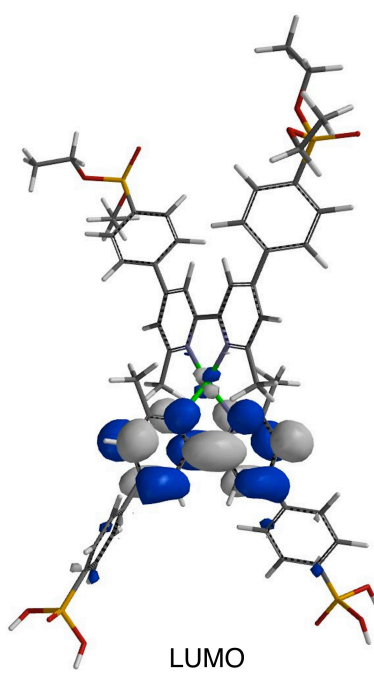

LUMO

(b)

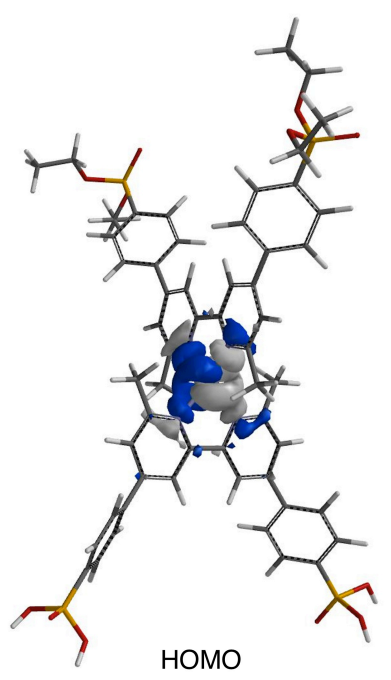

Fig. 7 (a) LUMO and (b) HOMO of [Cu(1)(dmbpy) $]^{+}$. (b) LUMO and (b) HOMO of $[\mathrm{Cu}(\mathbf{1})(2)]^{+}$. The anchoring ligand is at the bottom of the figures in each case.

\section{Conclusions}

We conclude from this investigation that using phosphonate ester $\mathbf{2}$ as an anchoring domain leads to poorer performing n-type DSCs than those in which the phosphonic acid anchoring ligand $\mathbf{1}$ is used. However, solid-state absorption spectroscopic data support that fact that dyeattachment to $\mathrm{TiO}_{2}$ does occur when $\mathbf{2}$ is used and this may be through in situ deprotection to the monoester and/or the phosphonic acid. Deprotection of the ester to the phosphonic acid anchoring ligand $\mathbf{1}$ is a prerequisite during the surface-bound dye-assembly process, and we are currently investigating different methods to achieve this in situ on the semiconductor surface. DSCs containing the dyes $[\mathrm{Cu}(\mathbf{1})(\mathrm{dmbpy})]^{+}$or $[\mathrm{Cu}(\mathbf{1})(\mathbf{2})]^{+}$show comparable 
conversion efficiencies of $\approx 2 \%$. The EQE spectra for the DSCs with these dyes are similar, showing broad bands with $\lambda_{\max }$ around $460-480 \mathrm{~nm}$ and $\mathrm{EQE}_{\max }=40 \%$.

\section{Acknowledgements}

We thank the European Research Council (Advanced Grant 267816 LiLo), the Swiss National Science Foundation and the University of Basel for financial support. We thank Dr Biljana Bozic-Weber for discussions.

\section{References}

[1] M. Grätzel, Inorg. Chem., 44 (2005) 6841.

[2] A. Reynal, E. Palomares, Eur. J. Inorg. Chem. (2011) 4509.

[3] A. Mishra, M. K. R. Fischer, P. Bäuerle, Angew. Chem. Int. Ed. 48 (2009) 2474.

[4] B. Bozic-Weber, E. C. Constable, C. E. Housecroft, Coord. Chem. Rev. 257 (2013) 3089.

[5] T. E. Hewat, L. J. Yellowlees, N.Robertson, Dalton Trans. 43 (2014) 4127.

[6] K. A. Wills, H. J. Mandujano-Ramírez, G. Merino, D. Mattia, T. Hewat, N. Robertson, G. Oskam, M. D. Jones, S. E. Lewis, P. J. Cameron, RSC Adv. 3 (2013) 23361.

[7] A. Colombo, C. Dragonetti, D. Roberto, A. Valore, P. Biagini, F. Melchiorre, Inorg. Chim. Acta 407 (2013) 204.

[8] B. Bozic-Weber, S. Y. Brauchli, E. C. Constable, S. O. Fürer, C. E. Housecroft, F. J. Malzner, I. A. Wright, J. A. Zampese, Dalton Trans. 42 (2013) 12293.

[9] J. Baldenebro-Lopez, N. Flores-Holguin, J. Castorena-Gonzalez, D. Glossman-Mitnik, J. Photochem. Photobiol. A 267 (2013) 1. 
[10] M. Sandroni, M. Kayanuma, A. Planchat, N. Szuwarski, E. Blart, Y. Pellegrin, C. Daniel, M. Boujtita, F. Odobel, Dalton Trans. 42 (2013) 10818.

[11] A. Hernandez Rendondo, E. C. Constable, C. E. Housecroft, Chimia 63 (2009) 205.

[12] Y. Pellegrin, M. Sandroni, E. Blart, A. Planchat, M. Evain, N. C. Bera, M. Kayanuma, M. Sliwa, M. Rebarz, O. Poizat, C. Daniel, F. Odobel, Inorg. Chem. 50 (2011) 11309 and references therein.

[13] B. Bozic-Weber, E. C. Constable, C.E. Housecroft, P. Kopecky, M. Neuburger, J. A. Zampese, Dalton Trans. 40 (2011) 12584.

[14] P. Péchy, F. P. Rotzinger, Md. K. Nazeeruddin, O. Kohle, S. M. Zakeeruddin, R. Humphry-Baker, M. Grätzel, J. Chem. Soc., Chem. Commun. (1995) 65.

[15] S. M. Zakeeruddin, M. K. Nazeeruddin, P. Pechy, F. P. Rotzinger, R. Humphry-Baker, K. Kalyanasundaram, M. Grätzel, V. Shklover, T. Haibach, Inorg. Chem. 36 (1997) 5937.

[16] H. Zabri, I. Gillaizeau, C. A. Bignozzi, S. Caramori, M.-F. Charlot, J. Cano-Boquera, F. Odobel, Inorg. Chem. 42 (2003) 6655.

[17] D. K. Zhong, S. Zhao, D. E. Polyansky, E. Fujita, J. Catal. 307 (2013) 140.

[18] F. C. Krebs, M. Biancardo, Solar Ener. Mater. Solar Cells 90 (2006) 142.

[19] E. C. Constable, C. E. Housecroft, M. Šmídková, J. A. Zampese, Can. J. Chem. (2014) in press.

[20] G. Guerrero, P. H. Mutin, A. Vioux, Chem. Mater. 13 (2001) 4367.

[21] G. Guerrero, P. H. Mutin, E. Framery, A. Vioux, New J. Chem. 32 (2008) 1519.

[22] A. Vioux, J. Le Bideau, P. H. Mutin, D. Leclercq, Top. Curr. Chem. 232 (2004) 145.

[23] W. W. Brandt, F. P. Dwyer, E. D. Gyarfas, Chem. Rev. 54 (1954) 959.

[24] G. J. Kubas, Inorg. Synth. 28 (1990) 68. 
[25] B. Bozic-Weber, V. Chaurin, E. C. Constable, C. E. Housecroft, M. Meuwly, M. Neuburger, J. A. Rudd, E. Schönhofer, L. Siegfried, Dalton Trans. 41 (2012) 14157.

[26] S. Ito, T. N. Murakami, P. Comte, P. Liska, C. Grätzel, M. K. Nazeeruddin, M. Grätzel, Thin Solid Films, 2008, 516, 4613.

[27] H. J. Snaith, Energy Envir. Sci. 5 (2012) 6513.

[28] B. Bozic-Weber, S. Y. Brauchli, E. C. Constable, S. O. Fürer, C. E. Housecroft, I. A. Wright, Phys. Chem. Chem. Phys. 15 (2013) 4500.

[29] T. Bessho, E. C. Constable, M. Grätzel, A. Hernandez Redondo, C. E. Housecroft, W. Kylberg, Md. K. Nazeeruddin, M. Neuburger, S. Schaffner, Chem. Commun. (2008) 3717. 